\title{
Biodiversity of the phosphate solubilizing microorganisms (PSMs) population from the rice rhizosphere soils of the two agro-ecological zones of Cameroon
}

\author{
Henri FANKEM $^{1 *}$, Hélène Laure MAFOKOUA ${ }^{1}$, Laurette NGO NKOT ${ }^{1}$, Claude SIMO $^{1}$, \\ Donald TCHOUOMO DONDJOU ${ }^{1}$, Gylaine Vanissa TCHUISSEU TCHAKOUNTE ${ }^{1}$, \\ Dieudonné NWAGA ${ }^{2}$ and François-Xavier ETOA ${ }^{2}$
}

${ }^{1}$ Department of Plant Biology, Faculty of Science, University of Douala, Douala, Cameroon.

${ }^{2}$ Department of Microbiology, Faculty of Science, University of Yaoundé I, Yaoundé, Cameroon. *Corresponding author; E-mail: fankemhenri@yahoo.fr

\begin{abstract}
The plant rhizosphere microorganisms having the phosphate solubilizing capacity can convert the insoluble soil organic and inorganic phosphates into a soluble form and make the phosphorus $(\mathrm{P})$ available to the plant. With the objective of evaluating the phosphate solubilizing microorganism populations under the rice rhizosphere, soils samples were collected in three locations of two agro-ecological zones of Cameroon and analyzed for their PSMs diversity. Isolation of microorganisms was made on non selective nutrient agar plates and the phosphate solubilizing activity of isolates was tested on National Botanical Research Institute's Phosphate growth medium (NBRIP) amended with sparingly soluble rock phosphates of different origins. The morphological description of isolates allowed evaluating the phosphate solubilizing microorganism's diversity under the rice rhizospheric soil. The most probable number of PSMs ranged between 22 and 53\% with an average of $48 \%, 52.80 \%$ and $22.44 \%$ for Nkolbisson, Nyokon and Santchou respectively. The 65 isolates obtained from all locations were distributed in four diverse groups. The index of solubilization ranged between 2.70 and 7.24 depending on isolate. From a total of 65 isolates obtained from the three sampling sites, 46 were phosphate solubilizing isolates among which: 20 were of low solubilization, 16 of medium and 10 of high solubilization. This is the first work reporting phosphate solubilizing microorganisms on rice rhizosphere in Cameroon. However, the selection of phosphate solubilizing microorganisms as possible inoculation tools for phosphate-deficient soils should focus on the integral interpretation of laboratory assays, greenhouse experiments as well as field trials.
\end{abstract}

(c) 2015 International Formulae Group. All rights reserved.

Keywords: Diversity, index of solubilization, isolates, rice, rock phosphates.

\section{INTRODUCTION}

Phosphorus $(\mathrm{P})$ is an essential mineral nutrient required for plant growth because it is a major component of important molecules (Collavino et al., 2010). It is intimately involved in a wide range of physiological and biochemical processes that include; cellular energy systems, structure and function of nucleic acids (Antoun, 2012), membrane integrity and sugar metabolism (Richardson, 2009). Orthophosphate anions (mainly $\mathrm{H}_{2} \mathrm{PO}_{4}{ }^{-}$ and $\mathrm{HPO}_{4}{ }^{2-}$ ) are the form of $\mathrm{P}$ taken up by plants from soil solution; however their concentration is very low because they are chemically very active and they react rapidly with cations like calcium in alkaline soils or aluminum and iron in acid soils to form sparingly soluble precipitates, not available to plants (Antoun, 2012; Oteini et al., 2015). The overuse of chemicals and chemical fertilizers as an alternative to overcome the P deficiency has led to the lethal consequences to useful 
arthropods and other beneficial microbes as well as led to soil pollution (Popavath Ravindra Naik et al., 2008). Furthermore, the efficiency of applied phosphorus rarely exceeds $30 \%$ due to fixation in soil (Sharma et al., 2013).

Nowadays, the new approach to farming, often referred to as sustainable agriculture, requires agricultural practices that are friendlier to the environment and that maintain the long-term ecological balance of the soil ecosystem (Khan et al., 2009). In this context, the use of microbial inoculants (biofertilizers) including PSM in agriculture represents an environment friendly alternative to further applications of mineral fertilizers. The association between PSM and plant roots plays a key role in $\mathrm{P}$ nutrition in many agro ecosystems, particularly in P-deficient soils (Goldstein 2007; Jorquera et al., 2008). Although several phosphate solubilizing bacteria (PSB) occur in soil and in plant rhizosphere, the amount of $P$ released by these micoorganisms is generally not sufficient to fulfill the requirements of growing plants (Rodríguez et al., 2006). The inoculation of plants with selected PSB to increase native population can mobilize $\mathrm{P}$ from poorly available sources and therefore improve plant nutrition (Richardson 2001; Guiñazu et al., 2010). Phosphate Solubilizing Microbes (PSM) has the potential to reduce application rates of phosphate fertilizer by $50 \%$ without significantly reducing crop yield (Yazdani et al., 2009). Phosphate Solubilizing Bacteria (PSB) may also be useful in the phytoremediation of heavy metal impacted soil (Ahemad, 2015; Monica and Harshada, 2015) or for bioleaching of rare Earth elements for mined ores (Shin et al., 2015). Among the alternative $\mathrm{P}$ sources, the most important are locally available rock phosphate (RP) resources. While the use of commercial Pfertilizers is not cost effective, rock phosphate as a source of $\mathrm{P}$ is not expensive but the availability of P is low (Jayadi et al., 2013). Not all of the RP resources are readily plant available and agronomically reactive when applied directly to the soils.

It is generally accepted that the mechanism of mineral phosphate solubilization by PSB strains is associated with the release of low molecular weight organic acids (Kim et al., 1997; Fankem et al.,
2008), which through their hydroxyl and carboxyl groups chelate the cations bound to phosphate, thereby converting it into soluble forms (Kpomblekou and Tabatabai, 1994). Continued exploring the natural biodiversity of soil microorganisms and the optimization/manipulation of microbial interactions in the rhizosphere represents a prerequisite step to develop more efficient microbial inoculants with phosphate solubilizing ability.

Therefore, knowledge on biodiversity of phosphate solubilizing microorganisms is essential to understand their ecological role and their utilization in sustainable agriculture.

The aim of this research is to evaluate the phosphate solubilizing microorganism populations in the rice rhizosphere from two agro-ecological zones of Cameroon.

\section{MATERIALS AND METHODS \\ Sampling sites}

The soil samples were collected in three locations located in two agro-ecological zones of Cameroon (Figure 1). The Santchou locality in the agro-ecological zone III, characterized by an equatorial mountain climate and high rainfall (2000 to $3000 \mathrm{~mm}$ ). Temperatures are fairly fresh for several months and the dry period is very short and lasts more than 2 months (Martin and Segalen, 1966). Located between $9^{\circ} 50^{\prime}$ and $10^{\circ} 06^{\prime}$ North latitude and between $5^{\circ} 20^{\prime}$ and $5^{\circ} 12^{\prime}$ longitude East, Santchou is an area estimated to approximately $900 \mathrm{~km}^{2}$, with reddish soils, ferralitiques melanized, existing on the volcanic hills of the Eastern part of West Cameroon (Claisse and Laplante, 1953). Here, sampling was made on an area of $500 \mathrm{~m}^{2}$, intended mainly to the rice cultivation within the five past years.

The agro-ecological zone $\mathrm{V}$, composed of Nkolbisson and Nyokon localities, is a moist forest zone with bimodal rainfall of about $1545 \mathrm{~mm} /$ year, with maxima in May and October. The annual average temperatures range between $23{ }^{\circ} \mathrm{C}$ (July and August) and $26{ }^{\circ} \mathrm{C}$ in February (Fankem, 2007). It is situated below $3^{\circ} 52^{\prime}$ North latitude and under $11^{\circ} 32^{\prime}$ longitude (Bachelier, 1959). That zone is characterized by ferralitique, reddish or yellowish soils according to locations (Ambassa-Kiki and Babalola, 2000). Soil samples were collected on IRAD 
Nkolbisson's experimental field of $500 \mathrm{~m}^{2}$ of 2 years rice cultivation, and in Nyokon farm field of tha where rice is grown for the first time (Figure 1).

\section{Sampling}

The sampling technique consisted of zigzag sampling because it takes into account the intrinsic variability of soil related to the land use and cultural practices. A composite soil sample was obtained by mixing 30 subsamples collected at the rhizosphere of rice plants from 0 to $30 \mathrm{~cm}$ depth. Samples were taken into sterile containers and took to the laboratory where they were air dried, crushed and a part sieved with a $2 \mathrm{~mm}$ sieve mesh to remove pebbles and large organic debris while the other part remained unsieved for soil physico-chemical analysis. The samples were kept in sterile plastics bags and stored in the refrigerator at $4{ }^{\circ} \mathrm{C}$ for further biological analysis.

Evaluation of the most probable number of phosphate solubilizing microorganisms

The most probable number of microorganisms solubilizing phosphate was evaluated on NBRIP medium (Nautiyal, 1999) containing per liter of distilled water: glucose $20 \mathrm{~g} ; \mathrm{MgCl}_{2} \cdot 6 \mathrm{H} 20.5 \mathrm{~g} ; \mathrm{MgSO}_{4} \cdot 7 \mathrm{H}_{2} \mathrm{O} 0.25 \mathrm{~g}$; $\mathrm{KCl}, 0,2 \mathrm{~g}$; $\left(\mathrm{NH}_{4}\right)_{2} \mathrm{SO}_{4} 0,1 \mathrm{~g} ; \mathrm{Ca}_{3}\left(\mathrm{PO}_{4}\right)_{2} 5.02$ $\mathrm{g}$, Agar $15 \mathrm{~g}$; pH 7.2. For this evaluation, $5 \mathrm{~g}$ of soil sample were suspended in $45 \mathrm{ml}$ of sterile distilled water. After stirring and homogenization, decimal dilutions were made $10^{-1}$ to $10^{-7}$ dilution. One (1) $\mathrm{ml}$ of $10^{-5}, 10^{-6}$ and $10^{-7}$ dilution was introduced into sterile Petri dishes in triplicate, which subsequently received approximately $12 \mathrm{ml}$ of NBRIP medium. After 5 days incubation at $28^{\circ} \mathrm{C}$, the total number of microorganisms and the number of microorganisms showing halo zone around their colonies were assessed by visual and direct counting.

\section{Isolation of microorganisms}

The isolation of microorganisms was made on non-selective medium to allow the greatest diversity of microorganisms to grow. To do this, $5 \mathrm{~g}$ of soil were suspended in 45 $\mathrm{ml}$ of sterile distilled water. After stirring and homogenization, decimal dilutions were made as described above. One (1) $\mathrm{ml}$ of $10^{-5}, 10^{-6}$, $10^{-7}$ dilution was introduced in sterile Petri dishes that further received about $12 \mathrm{ml}$ nutrient agar containing per liter of distilled water: $\mathrm{NaCl}, 3 \mathrm{~g}$; Yeast extract, $3 \mathrm{~g}$; Peptone, $5 \mathrm{~g}$; Agar, $15 \mathrm{~g}$; pH 7. The Petri dishes were then incubated at $28{ }^{\circ} \mathrm{C}$ for 5 days. The different bacterial colonies were transferred into new Petri dishes containing the same medium. The operation was repeated several times until obtaining pure bacterial colonies. The obtained isolates were kept in tubes containing the same medium and stored in at 4 ${ }^{\circ} \mathrm{C}$. The tubes were renewed every two months to maintain the isolates viable.

\section{Assessment of the diversity of isolates}

The diversity of the isolates was made from the macroscopic description of the bacterial colonies. It was based on the shape (round, irregular, star and invasive), relief (convex, flat concentric wave), the contour (regular, irregular), size (very small colony, $\phi<1 \mathrm{~mm}$; small colony, $1<\phi<2 \mathrm{~mm}$; average colony, $3<\phi<5 \mathrm{~mm}$; big colony, $\phi>5 \mathrm{~mm}$ ), surface (smooth, rough) and color. This description allowed highlighting the similarities and the differences between isolates. The construction of the phylogenetic dendrograms was made using SLSTAT Software version 2014.

Assessment of the ability of isolates in solubilizing rock phosphate of different origins in solid medium

\section{Rock phosphates}

Four rock phosphates from different origins have been used, including the Malian (total P, 30\%; available P, 12.98\%) Mexican (total P, 28\%; available P, $8.87 \%$ ), Moroccan (total P, 13\%; available $\mathrm{P}, 9.33 \%$ ) and Algerian (total P, 29\%; available $\mathrm{P}$, nd) rock phosphates (Fankem et al., 2014). In order to get rid of their soluble factions, they have been washed 4 times with warm water following the cycle: 1 hour - 24 hours - 1 hour - 24 hours. They were then oven dried at 60 ${ }^{\circ} \mathrm{C}$ until complete evaporation of the water and then homogenized before use.

\section{Preparation and evaluation of the concentration of the inoculums}

To prepare inoculums from each bacterial strain, pure bacterial colony was individually suspended into $50 \mathrm{ml}$ Nutrient Broth (NB) (5 g Peptone, $1 \mathrm{~g}$ Beef extract, $2 \mathrm{~g}$ Yeast extract, $5 \mathrm{~g}$ Sodium chloride, $1000 \mathrm{ml}$ 
Distilled water, $\mathrm{pH}$ 7.0) and incubated at 28 ${ }^{\circ} \mathrm{C}, 150 \mathrm{rpm}$, for 3 days. Cultures were then centrifuged at $10.000 \mathrm{~g}$ for 10 minutes at $4{ }^{\circ} \mathrm{C}$, followed by three washing with $0.85 \%$ sterile $\mathrm{NaCl}$ at the same conditions. Bacterial cells were re-suspended in $0.85 \%$ sterile $\mathrm{NaCl}$ and the optical density (OD) of the suspension adjusted to 0.2 at $620 \mathrm{~nm}$ wavelength. To assess the number of bacterial cells per milliliter, one $\mathrm{ml}$ of the bacterial suspension with OD 0.2 was serial diluted until $10^{-7}$. A $200 \mu \mathrm{l}$ of dilutions $10^{-7}$ was used to inoculate Nutrient Agar (NA) (5 g Peptone, 1 g Beef extract, $2 \mathrm{~g}$ Yeast extract, $5 \mathrm{~g}$ Sodium chloride, 15 g Agar, $1000 \mathrm{ml}$ Distilled water, $\mathrm{pH}$ 7.0) plates in duplicate. After incubation at $28{ }^{\circ} \mathrm{C}$, for 4 days, bacterial colonies were counted and the number of Colony Forming Unit (CFU) per $\mathrm{ml}$ evaluated. Counting colonies allowed the determination of the concentration of the inoculums of $4.5-5 \times 10^{8}$ $\mathrm{CFU} / \mathrm{ml}$.

Activity of isolates on plates

Evaluation of the ability of all isolates in solubilizing the different types of phosphate was made in Petri dishes containing NBRIP medium (Nautiyal, 1999) as previously described. Sterile Petri dishes were subdivided into four compartments and the centre of each compartment received $3 \mu \mathrm{l}$ of bacterial suspension obtained as previously described. The operation was performed in triplicate to allow the statistical analyses. Incubation was made at $28{ }^{\circ} \mathrm{C}$ for five days within which the index of solubilization was recorded according to Qureshi et al. (2012): "IS = (diameter of the colony + diameter of halo zone)/(diameter of the colony)".

\section{Statistical analysis}

Statistical analyses were performed with Sigma plot 12.0. The analysis of variance (ANOVA) was run to find difference between factors and the HSD Turkey test to compare the different treatments means at $\mathrm{p}<0.05$.

\section{RESULTS}

Characteristics of soils of the different sites

The physico-chemical analyses of soils samples from different sites have shown different characteristics from each other (Table 1). In general, soils are all acidic soils with a $\mathrm{pH}$ of 4.87 for Nkolbisson, 5.52 for Nyokon and 4.76 for Santchou. The amounts of available phosphorus in general are low with respectively $15.42,10.61$ and $6.54 \mathrm{mg} / \mathrm{kg}$ for Nkolbisson, Santchou and Nyokon. Organic matter in Nyokon soil (50.53 mg/kg), is much more higher than those of Nkolbisson (35.77 $\mathrm{mg} / \mathrm{kg}$ ) and Santchou (17.15 mg/kg). The bases exchangeable $\left(\mathrm{Ca}^{2+}, \mathrm{Mg}^{2+}, \mathrm{K}^{+}\right.$, and $\mathrm{Na}^{+}$) are more represented in soil of Nyokon, followed by that of Nkolbisson and Santchou. The Cation Exchange Capacity (CEC) decreases from Nyokon soil (12.52 Cmol $/ \mathrm{kg}$ ) Santchou $(9.73 \mathrm{Cmol} / \mathrm{kg})$ and Nkolbisson (8.99 Cmol/kg) (Table 1).

\section{The most probable number of phosphate solubilizing microorganisms \\ The phosphate solubilizing} microorganisms was viewed over the non solubilizers microorganisms through the halo zone (translucent) around their colonies. In general the values of the most probable number of PSM ranged between 22 and $53 \%$. The soil from Nkolbisson showed a total microorganism number of $25 \times 10^{7}$ out of which $12 \times 10^{7}(48 \%)$ were PSM. At Nyokon, a total microorganism number was $6.34 \times 10^{7}$ with $3.35 .10^{7}$ PSM (52.80\%), while Santchou sample showed a total microorganism number of $49.43 .10^{7}$ with $10.8 \times 10^{7}$ PSM, accounting for $22.44 \%$ (Table 2).

\section{Isolation of microorganisms}

The different isolates were obtained on the basis of their morphological and physical characteristics. A total of 65 isolates were obtained from the three soil samples. Rhizospheric soils of Nkolbisson and Nyokon allowed obtaining 23 isolates that have been labeled NK and NY respectively, while 19 isolates were obtained from Santchou and labeled SA.

\section{Diversity of isolates from the rice rhizosphere of the different sites Diversity of isolates from Nkolbisson soil sample}

The results shows some similarities and dissimilarities between isolates obtained from soil sample collected at Nkolbisson. Three broad groups are represented in this case with similarity index ranging between 200 and $300 \%$ (Figure 2a). Isolates within the same group are closer each to others than in the different groups. 
The first group (I) is represented by seven isolates among which: NK44, NK41, NK43, NK42, NK32, NK31 and NK21. Among the seven isolates, five (NK44, NK41, NK43, NK32 and NK31) was characterized as rock phosphate solubilizers. The second group (II) is represented only by NK10 that is a rock phosphate solubilizer, while the third group (III) is constituted of fifteen isolates (NK16, NK14, NK24, NK22, NK17, NK23, NK19, NK11, NK2, NK9, NK6, NK8, NK13, NK3, NK1) among which only three (NK22, NK23, NK19) did not show the rock phosphates solubilizing capacity.

Diversity of isolates from Nyokon soil sample

The results show some similarities and dissimilarities between isolates obtained from this soil sample collected in Nyokon rice field. Three broad groups are also represented here with a dissimilarity index below 100 (Figure $2 b)$.

Like in Nkolbisson rice field, 23 isolates were obtained from the soil sample collected in this area, among which a total of 18 have displayed the aptitude for rock phosphate solubilization. The first group is made of two isolates (NY10 and NY22), both the rock phosphate solubilizers. The second group is constituted of 7 isolates (NY14, NY15, NY16, NY17, NY18, NK20 and NY21) among which only NY16 could not displayed the aptitude in solubilizing the different rock phosphates. The third group is the most diverse and consists of 14 isolates (NY1 NY2 NY3 NY4, NY7, NY8, NY9, NY11, NY12, and NY13) among which ten solubilizers, the rock phosphates being recalcitrant to NY19, NY7, NY23 and NY1.

Diversity of isolates from Santchou soil sample

The results show some similarities and dissimilarities between the isolates obtained from that soil sample. Four major groups are represented at a less than $50 \%$ similarity index (Figure 2c). A total of 19 isolates distributed into four main groups were obtained from soil sample collected in Santchou rice field.

The first group is constituted of four isolates (SA12, SA5, SA1 and SA15) with $50 \%$ of rock phosphate solubilizers (SA5 and $\mathrm{SA} 1)$. The second group is the most diverse and consisted of 8 isolates (SA3, SA2, SA11, SA18, SA13, SA9, SA8 and SA6) among which only two (SA3 and SA8) did not showed ability in solubilizing rock phosphates. The third group consisted of 6 isolates (SA22, SA19, SA16, SA10, SA14 and SA23) among which only one (SA10) was not able to solubilize rock phosphates. The last group, the fourth is made of only one isolate (SA21) which is also a rock phosphate solubilizer

\section{Diversity of combined isolates from the different sites}

While grouping all the isolates (65) obtained from the different locations, the results allow seeing the closer relationships between all isolates, with the total number of groups not far from those obtained in a single location. Four major groups are represented at a level of $250 \%$ similarity index (Figure 3 ). The first group is the wider group constituted of 33 isolates, representing $51 \%$ of the total isolates. Among these, there are $12(36.4 \%), 7$ $(21.2 \%)$ and $14(42.4 \%)$ for Santchou, Nkolbisson and Nyokon respectively.

The second group is made of 19 isolates representing $29 \%$ of the total isolates among which there are $6(31.6 \%), 6(31.6 \%)$ and $7(36.8 \%)$ for Santchou, Nkolbisson and Nyokon respectively. The third group consisted of $12(18 \%)$ isolates of the total. Among these, there are $1(8.3 \%), 9(75.0 \%)$ and $2(16.7 \%)$ for Santchou, Nkolbisson and Nyokon respectively. The last and the smallest group is represented only by one isolate ( $2 \%$ of the total isolates) of Nkolbisson.

\section{Ability of isolates in solubilizing rock phosphate of different origins in solid media}

The screening of isolates in Petri dishes amended with different rock phosphates allowed the determination of their ability in solubilizing these rock phosphates.

\section{Isolates from Nkolbisson soil sample}

The results indicate that 18 isolates over 23 have solubilized at least one rock phosphate type. The Algerian and Malian rock phosphates were solubilized by most of isolates (15). The Mexican RP showed five solubilizations over 18, while the Moroccan rock phosphate was the most recalcitrant with only one solubilization (Table 3).

The rock phosphate solubilization varies from one isolate to another. Significant differences in the solubilization ability of the different isolates are noted. Therefore, NK43 
isolate was the only one able to solubilize all the four rock phosphate types, while three isolates (NK44, NK40 and NK31) showed positive activity on three RP (Algeria, Mali and Mexico) over the four tested. Regarding the Algerian RP, NK10 is the isolate that showed the greatest solubilization ability with an index of solubilization of 5.8 while NK2, NK11, NK16 and NK24 were not able to solubilize the Algerian RP. As far as concern the Malian RP, NK16 and NK13 are the most efficient isolates with an index of 5.3 and 5 respectively. On the other hand, NK6 is the only isolate unable to dissolve this type of phosphate. NK43 is the most efficient isolate with an index of solubilization of 3.5 and the only one that was able to solubilize the Moroccan rock phosphate. For Mexican RP, NK43 remains the most efficient isolate with an index of 5.24; it is followed by NK31, NK16, NK44 and NK40 with the index of 4.7, $4.5,3.7$ and 2.9 respectively.

It appears from this result that the most efficient isolate is the NK43 with 4.3 as index of solubilization, followed by NK31 and NK44 with respectively 3.80 and 3.46 as index of solubilization (Table 3). The less efficient isolates are NK4 and NK2 with an index of solubilization of 1.71 and 1.75 respectively. The speed of solubilization also varied from one isolate to another. The fastest isolates (NK31 and NK17) showed the solubilization ability the first day, while isolates NK44, NK13, NK11, NK9, NK6, NK3, NK2 and NK1 could show the activity the second day. The slowest ones are: NK43, NK41, NK40, NK32, NK16, NK14, NK10 and NK8 could show the activity only the third day.

\section{Isolates from Nyokon soil sample}

Nineteen isolates over the 23 obtained from Nyokon soil sample showed an ability to solubilize at least one rock phosphate type. Significant differences in the solubilization ability of different isolates as well as the rock phosphate type are observed. One isolate (NY5) was able to solubilize all the four rock phosphate types (Table 4). Two isolates, NY10 and NY11 solubilized three rock phosphate types (Algerian, Malian and Mexican RP). Three isolates (NY6, NY12 and NY21) showed the activity only on plated supplemented with Malian RP. The Malian $\mathrm{RP}$ is the easiest RP that is solubilized by the
19 solubilizers. The Algerian RP is the second rock phosphate to be solubilized with 7 isolates over the 19, while the Mexican and Moroccan RP seem to be the most recalcitrant.

NY5 is the most efficient isolate on Malian RP with an index of solubilization of 6, followed by NY17 (IS=5.18). For Algerian $\mathrm{RP}, \mathrm{NY} 14$ is the most efficient isolate with an index of 4.63, followed by NY22 (IS=4.37), while for Moroccan RP, NY5 is the most efficient isolate with an index of 3.5. In addition, NY5 is the only one among the 19 isolates that is able to solubilize the Moroccan RP. NY11 is the most efficient isolate on Mexican RP with an index of 5.09, followed by NY5 (IS=3.51) and NY10 (IS=3.33).

The results indicate that NY11 is the isolate with the greatest ability in RP solubilization with an average index of 3.94 (Table 4); It is followed by NY10 with an index of solubilization of 3.65. The less efficient isolates are NY12, NY6 and NY21 with index of solubilization equal of 1.33 , 1.39 and 1.49 respectively.

The speed of solubilization of the different rock phosphates varied from one isolate to other. Twelve isolates (NY2, NY3 NY4, NY5, NY9, NY11, NY12, NY13, NY15, NY18, NY19 and NY20) over the 19 solubilizers showed the activity from the first day after incubation, 3 isolates (NY14, NY17, NY21) on the second day and finally, 4 isolates (NY6, NY8, NY10 and NY22) the third day (Table 4).

\section{Isolates from Santchou soil sample}

The same trend was seen as in other locations. Here, the solubilization depends on the isolate and according to the rock phosphate type. Significant differences are observed within isolates and within RP types (Table 5). The Malian rock phosphate is the easiest RP that was solubilized by 8 isolates over the 9; it is followed by the Algerian RP which is solubilized by 5 isolates. The Moroccan and the Mexican RP are the least solubilized with only 3 solubilizers. Two isolates, SA18 and SA19 were able to solubilize all the four rock phosphate types, while one isolate (SA23), solubilized 3 rock phosphates (Algerian, Malian and Moroccan $\mathrm{RP}$ ) over the four RP.

For Algerian RP, isolates SA18 and SA23 were the most efficient with respective 
index of solubilization of 5.77 and 5.59. While considering the Malian RP, SA23 is the most efficient isolate with an index of 4.94, followed by SA13 and SA1, which have respective index of solubilization of 4.42 and 4.43. Regarding the Moroccan RP, A23 is the most efficient isolate with an index of 4.57; it is followed by SA19 and SA18 with solubilization indexes respectively equal to 4.5 and 3.92. Mexican RP, SA9 is the most efficient isolate with an index of 7.24, the highest index obtained from all isolates. It is followed by SA18 and SA19 with index of solubilization respectively equal to 3.69 and 2.7 (Table 5).

Regarding the solubilization of the different RP, the isolate SA23 is the most efficient of all with an index of solubilization of 4.8, followed by SA18 isolate (4.17), while the least efficient isolate is SA22 with an index of solubilization of 1.4 (Table 5).

According to the facility of the different RP to be solubilized, the Malian RP was the easiest with an average index of 2.70, followed by Algerian RP (IS=2.20), the Moroccan and Mexican RP being the most recalcitrant RP with respectively 1.71 and 1.76 as index of solubilization.

While considering the speed of solubilization, two isolates (SA9 and SA23) solubilized faster than isolates SA5, SA13, SA18 and SA19 which solubilized the second day, and finally than SA1, SA2 and SA11 which showed activity only the third day.

\section{Solubilization according to the phosphate origin}

The solubilization of the different rock phosphates varied according to the phosphate type. Significant differences were observed within the solubilization rate of the different RP (Table 6). In general, the Malian rock phosphate appeared the most solubilized in all locations with index of solubilization ranging between 2.70 and 3.63, with an average of 3.28. The Algerian RP comes second with an average index of solubilization of 2.56 , followed by the Mexican RP with an average of 1.69. In all locations and in all cases, the Moroccan RP appeared the most recalcitrant RP for all isolates.

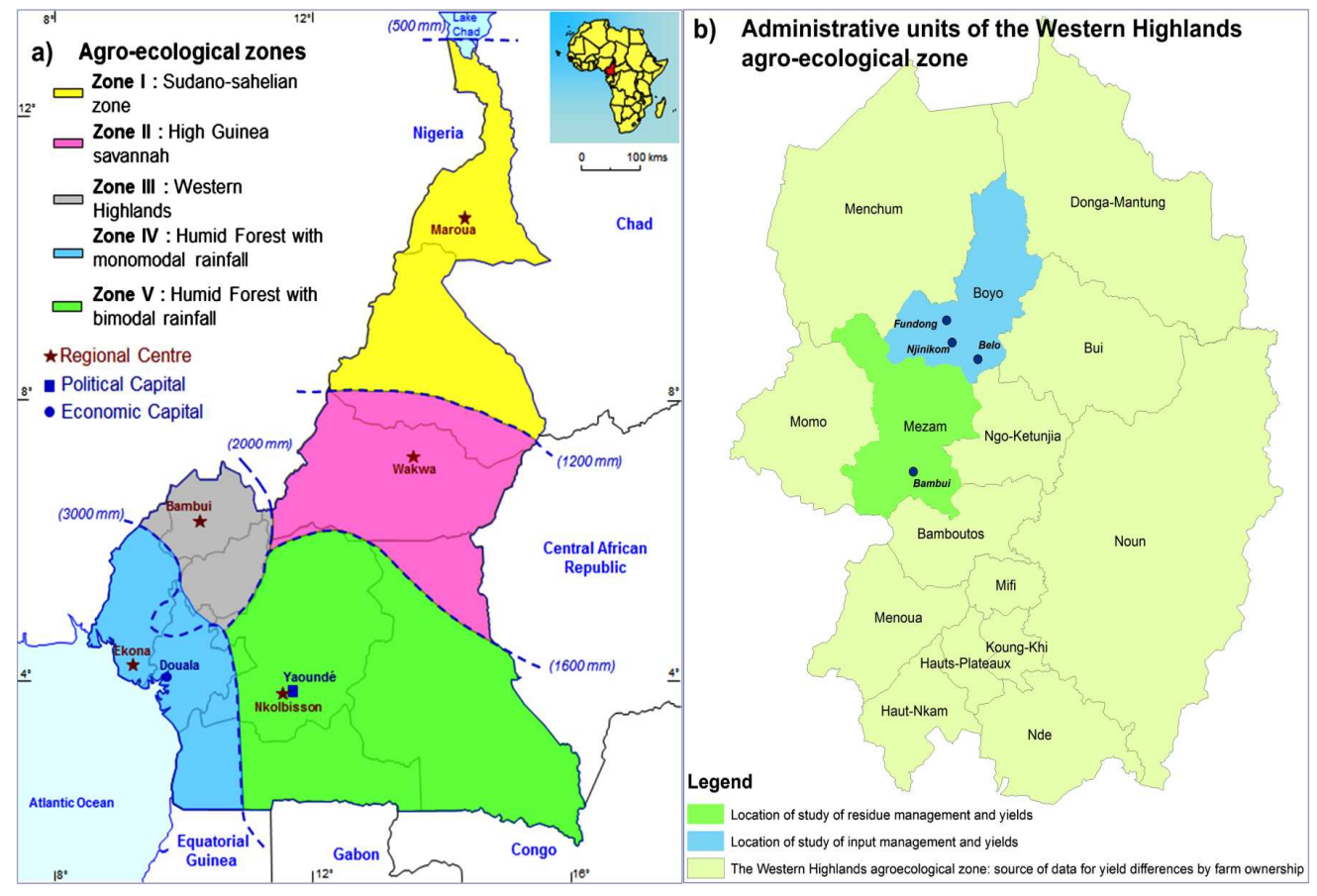

Figure 1: Sampling sites (yellow stars) in two out of the five agro-ecological zones of Cameroon: Nkolbisson and Nyokon in zone V (green color), Santchou in zone III (grey color). 
H. FANKEM et al. / Int. J. Biol. Chem. Sci. 9(5): 2284-2299, 2015
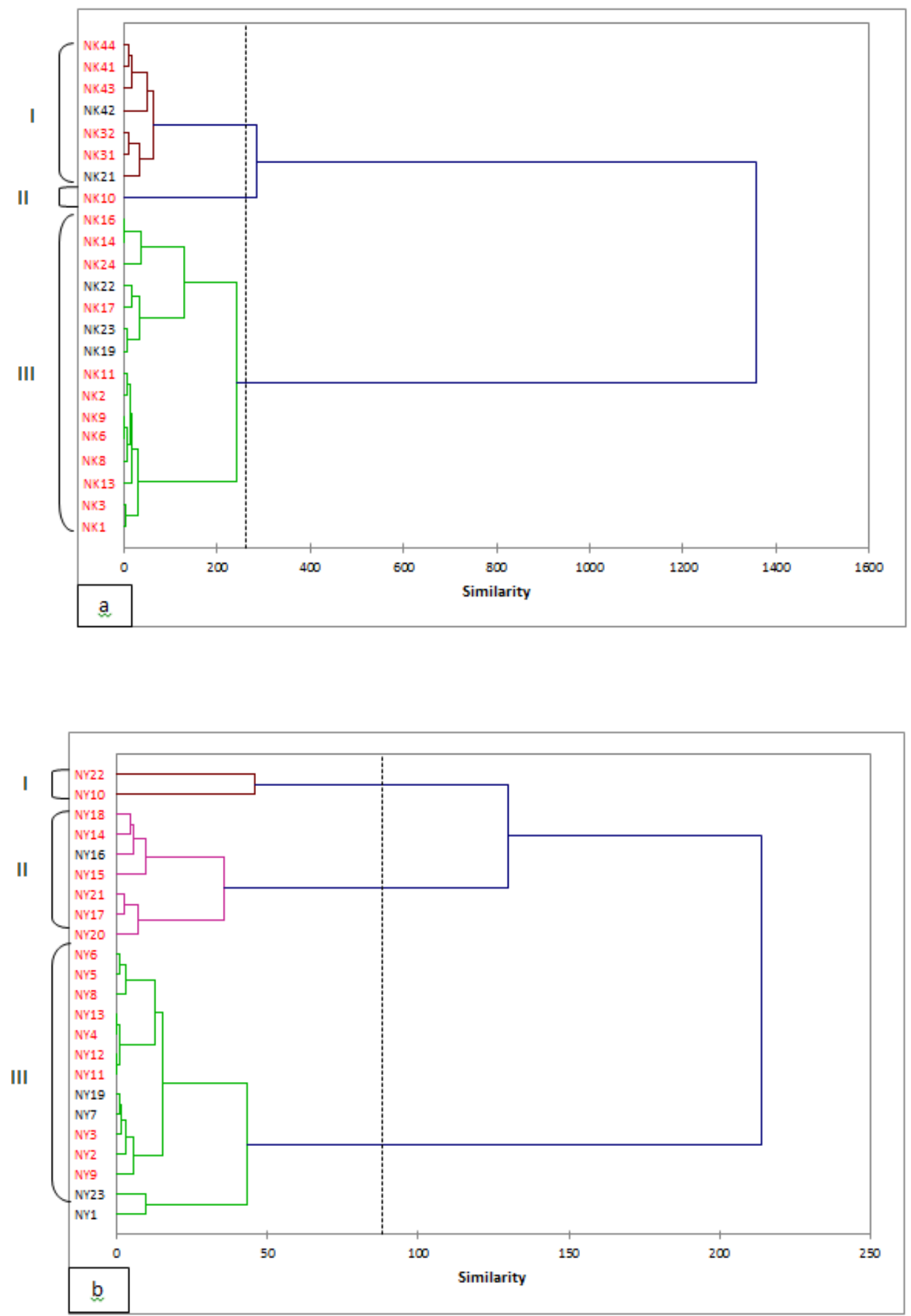


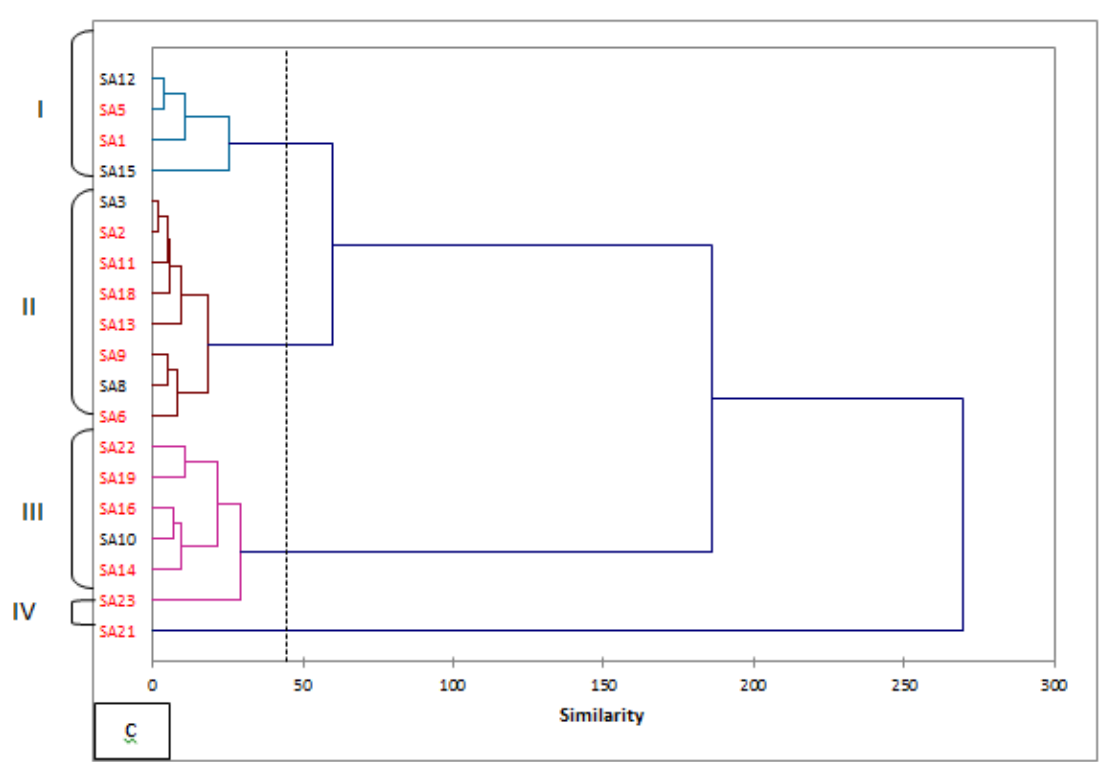

Figure 2: Dendrogram showing diversity within rock phosphate solubilizing isolates (in red color) obtained from soil samples collected at Nkobisson (a, similarity < 300\%), Nyokon (b, similarity < $100 \%$ ) and Santchou (c, similarity $<50 \%)$. Isolates are distributes into four main groups numbered I, II, III, IV.

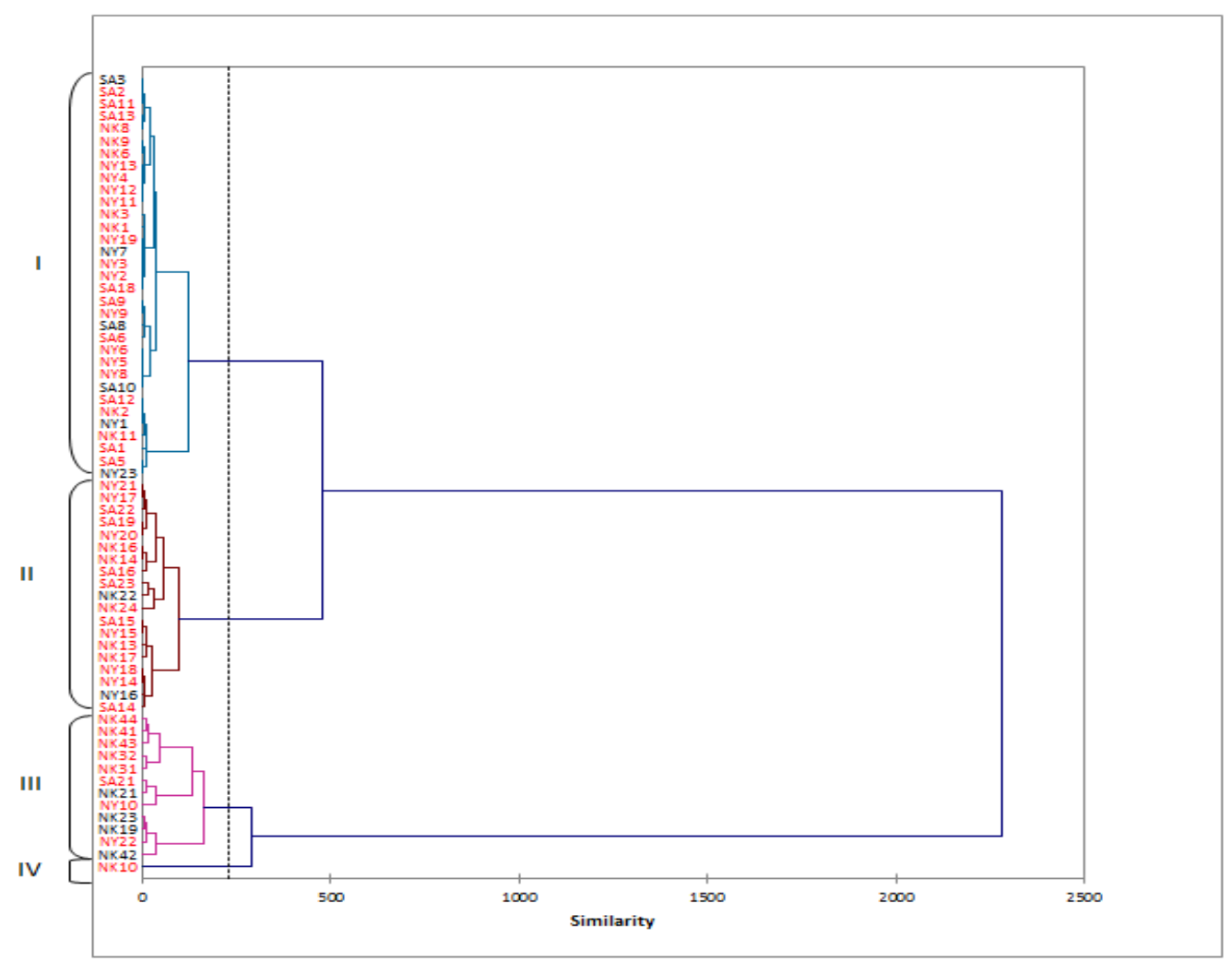

Figure 3: Dendrogram showing cumulative diversity within rock phosphate solubilizing isolates (in red color) obtained from soil samples collected at the three sampling sites (similarity < 250\%). Isolates are distributes into four main groups numbered I, II, III, IV. 
H. FANKEM et al. / Int. J. Biol. Chem. Sci. 9(5): 2284-2299, 2015

Table 1: Physico-chemical characteristics of the soil from the three sampling sites.

\begin{tabular}{|c|c|c|c|c|c|c|c|c|c|c|c|}
\hline \multirow{2}{*}{$\begin{array}{l}\text { Origin of } \\
\text { the soil }\end{array}$} & \multicolumn{6}{|c|}{ Element (mg/kg) } & \multicolumn{5}{|c|}{ Element (cmol/kg) } \\
\hline & pH & $\begin{array}{c}\text { Available } \\
\text { P }\end{array}$ & Org mat. & Org C & Total N & $\mathbf{C} / \mathbf{N}$ & $\mathrm{Ca}^{2+}$ & $\mathrm{Mg}^{2+}$ & $\mathbf{K}^{+}$ & $\mathrm{Na}^{+}$ & CEC \\
\hline Nkolbisson & 4.87 & 15.42 & 35.77 & 20.75 & 2.48 & 8.36 & 5.21 & 0.49 & 0.25 & 0.09 & 9.00 \\
\hline Nyokon & 5.52 & 6.54 & 50.53 & 29.31 & 2.86 & 10.26 & 7.20 & 1.17 & 0.39 & 0.13 & 12.52 \\
\hline Santchou & 4.76 & 10.61 & 17.15 & 9.95 & 1.76 & 5.64 & 1.91 & 0.28 & 0.22 & 0.07 & 9.73 \\
\hline
\end{tabular}

Org mat (Organic matter), Org C (Organic carbon), P (Phosphorus), CEC (Cation Exchange Capacity).

Table 2: The most probable number (MPN) of phosphate solubilizing microorganisms from soils collected in the three sampling sites.

\begin{tabular}{ccccc}
\hline $\begin{array}{c}\text { Number of microorganisms } \\
\left(\mathbf{1 0}^{\mathbf{7}} \mathbf{C F U}\right)\end{array}$ & \multicolumn{2}{c}{ Origin of the soil } \\
& Nkolbisson & Nyokon & Santchou & Total number \\
\hline Total number & 25 & 6.34 & 49.43 & 80.77 \\
Number of PSM & 12 & 3.35 & 10.80 & 26.15 \\
Pourcentage of PSM (\%) & 48 & 52.8 & 22.44 & 32.37 \\
\hline
\end{tabular}


Table 3: Solubilization of the different rock phosphates (RP) by isolates from Nkolbisson soil sample.

\begin{tabular}{|c|c|c|c|c|c|c|}
\hline \multirow[b]{2}{*}{ Isolates } & \multicolumn{5}{|c|}{ Index of solubilization (IS) } & \multirow{2}{*}{$\begin{array}{c}\text { Speed of } \\
\text { solubilization } \\
\text { (day) }\end{array}$} \\
\hline & $\begin{array}{c}\text { Algerian } \\
\text { RP }\end{array}$ & $\begin{array}{c}\text { Malian } \\
\text { RP }\end{array}$ & $\begin{array}{c}\text { Moroccan } \\
\text { RP }\end{array}$ & $\begin{array}{c}\text { Mexican } \\
\text { RP }\end{array}$ & Average & \\
\hline NK1 & 3.85 cde & 3.83 cde & $1.00 \mathrm{a}$ & $1.00 \mathrm{a}$ & $2.42 \mathrm{bc}$ & $2^{\text {nd }}$ \\
\hline NK2 & $1.00 \mathrm{a}$ & $2.83 \mathrm{~b}$ & $1.00 \mathrm{a}$ & $1.00 \mathrm{a}$ & $1.46 \mathrm{a}$ & $2^{\text {nd }}$ \\
\hline NK3 & 3.95 cde & $3.67 \mathrm{~cd}$ & $1.00 \mathrm{a}$ & $1.00 \mathrm{a}$ & $2.41 \mathrm{bc}$ & $2^{\text {nd }}$ \\
\hline NK6 & $4.77 \mathrm{fgh}$ & $1.00 \mathrm{a}$ & $1.00 \mathrm{a}$ & $1.00 \mathrm{a}$ & $1.94 \mathrm{~b}$ & $2^{\text {nd }}$ \\
\hline NK8 & $3.05 \mathrm{~b}$ & 4.15 cdef & $1.00 \mathrm{a}$ & $1.00 \mathrm{a}$ & $2.39 \mathrm{bc}$ & $3^{\text {rd }}$ \\
\hline NK9 & $4.93 \mathrm{gh}$ & $1.00 \mathrm{a}$ & $1.00 \mathrm{a}$ & $1.00 \mathrm{a}$ & $1.98 \mathrm{~b}$ & $2^{\text {nd }}$ \\
\hline NK10 & $5.80 \mathrm{i}$ & $1.00 \mathrm{a}$ & $1.00 \mathrm{a}$ & $1.00 \mathrm{a}$ & $2.20 \mathrm{bc}$ & $3^{\text {rd }}$ \\
\hline NK11 & $1.00 \mathrm{a}$ & $5.00 \mathrm{hi}$ & $1.00 \mathrm{a}$ & $1.00 \mathrm{a}$ & $2.00 \mathrm{~b}$ & $2^{\text {nd }}$ \\
\hline NK13 & $3.88 \mathrm{~cd}$ & $5.00 \mathrm{hi}$ & $1.00 \mathrm{a}$ & $1.00 \mathrm{a}$ & $2.72 \mathrm{c}$ & $2^{\text {nd }}$ \\
\hline NK14 & $4.98 \mathrm{~h}$ & 4.77 fghi & $1.00 \mathrm{a}$ & $1.00 \mathrm{a}$ & $2.94 \mathrm{~cd}$ & $3^{\text {rd }}$ \\
\hline NK16 & $1.00 \mathrm{a}$ & $5.30 \mathrm{i}$ & $1.00 \mathrm{a}$ & $4.54 \mathrm{~d}$ & $2.96 \mathrm{~cd}$ & $3^{\text {rd }}$ \\
\hline NK17 & $4.28 \mathrm{efg}$ & $4.47 \mathrm{efgh}$ & $1.00 \mathrm{a}$ & $1.00 \mathrm{a}$ & $2.69 \mathrm{c}$ & $1^{\mathrm{st}}$ \\
\hline NK31 & $4.22 \mathrm{def}$ & $4.90 \mathrm{ghi}$ & $1.00 \mathrm{a}$ & $4.71 \mathrm{de}$ & $3.71 \mathrm{~d}$ & $3^{\mathrm{rd}}$ \\
\hline NK32 & $3.60 \mathrm{bcd}$ & $3.70 \mathrm{~cd}$ & $1.00 \mathrm{a}$ & $1.00 \mathrm{a}$ & $2.33 \mathrm{bc}$ & $1^{\mathrm{st}}$ \\
\hline NK40 & $3.33 \mathrm{bc}$ & $3.61 \mathrm{c}$ & $1.00 \mathrm{a}$ & $2.94 \mathrm{~b}$ & $2.72 \mathrm{c}$ & $3^{\text {rd }}$ \\
\hline NK41 & $3.00 \mathrm{~b}$ & $2.81 \mathrm{~b}$ & $1.00 \mathrm{a}$ & $1.00 \mathrm{a}$ & $1.95 \mathrm{~b}$ & $3^{\text {rd }}$ \\
\hline NK43 & $4.43 \mathrm{efgh}$ & $4.30 \mathrm{defg}$ & $3.55 \mathrm{~b}$ & $5.24 \mathrm{e}$ & $4.38 \mathrm{e}$ & $3^{\text {rd }}$ \\
\hline NK44 & $3.00 \mathrm{~b}$ & $4.52 \mathrm{fgh}$ & $1.00 \mathrm{a}$ & $3.70 \mathrm{c}$ & $3.06 \mathrm{~cd}$ & $3^{\text {rd }}$ \\
\hline
\end{tabular}

Table 4: Solubilization of the different rock phosphates (RP) by isolates from Nyokon soil sample.

\begin{tabular}{|c|c|c|c|c|c|c|}
\hline \multirow[b]{2}{*}{ Isolates } & \multicolumn{5}{|c|}{ Index of solubilization (IS) } & \multirow{2}{*}{$\begin{array}{c}\text { Speed of } \\
\text { solubilization } \\
\text { (day) }\end{array}$} \\
\hline & Algerian RP & $\begin{array}{c}\text { Malian } \\
\text { RP }\end{array}$ & $\begin{array}{c}\text { Moroccan } \\
\text { RP } \\
\end{array}$ & $\begin{array}{c}\text { Mexican } \\
\text { RP }\end{array}$ & Average & \\
\hline NY2 & $1.00 \mathrm{a}$ & $2.83 \mathrm{ab}$ & $1.00 \mathrm{a}$ & $1.00 \mathrm{a}$ & $1.46 \mathrm{a}$ & $1^{\mathrm{st}}$ \\
\hline NY3 & $1.00 \mathrm{a}$ & $3.83 \mathrm{~cd}$ & $1.00 \mathrm{a}$ & $1.00 \mathrm{a}$ & $1.71 \mathrm{ab}$ & $1^{\text {st }}$ \\
\hline NY4 & $1.00 \mathrm{a}$ & $3.74 \mathrm{~cd}$ & $1.00 \mathrm{a}$ & $1.00 \mathrm{a}$ & $1.69 \mathrm{ab}$ & $1^{\mathrm{st}}$ \\
\hline NY5 & $4.10 \mathrm{de}$ & $6.00 \mathrm{~g}$ & $3.50 \mathrm{~b}$ & $3.51 \mathrm{~b}$ & $4.28 \mathrm{~d}$ & $1^{\text {st }}$ \\
\hline NY6 & $1.00 \mathrm{a}$ & $2.92 \mathrm{ab}$ & $1.00 \mathrm{a}$ & $1.00 \mathrm{a}$ & $1.48 \mathrm{a}$ & $3^{\text {rd }}$ \\
\hline NY8 & $1.00 \mathrm{a}$ & $4.04 \mathrm{de}$ & $1.00 \mathrm{a}$ & $1.00 \mathrm{a}$ & $1.76 \mathrm{ab}$ & $3^{\text {rd }}$ \\
\hline NY9 & $1.00 \mathrm{a}$ & $3.37 \mathrm{bc}$ & $1.00 \mathrm{a}$ & $1.00 \mathrm{a}$ & $1.59 \mathrm{ab}$ & $1^{\text {st }}$ \\
\hline NY10 & $3.40 \mathrm{bc}$ & $4.51 \mathrm{e}$ & $1.00 \mathrm{a}$ & $3.33 \mathrm{~b}$ & $3.06 \mathrm{c}$ & $3^{\text {rd }}$ \\
\hline NY11 & $3.77 \mathrm{~cd}$ & $3.62 \mathrm{~cd}$ & $1.00 \mathrm{a}$ & $5.09 \mathrm{c}$ & $3.37 \mathrm{c}$ & $1^{\mathrm{st}}$ \\
\hline NY12 & $1.00 \mathrm{a}$ & $2.64 \mathrm{a}$ & $1.00 \mathrm{a}$ & $1.00 \mathrm{a}$ & $1.41 \mathrm{a}$ & $1^{\text {st }}$ \\
\hline NY13 & $3.70 \mathrm{~cd}$ & $2.53 \mathrm{a}$ & $1.00 \mathrm{a}$ & $1.00 \mathrm{a}$ & $2.06 \mathrm{~b}$ & $1^{\mathrm{st}}$ \\
\hline NY14 & $4.63 \mathrm{e}$ & $3.43 \mathrm{c}$ & $1.00 \mathrm{a}$ & $1.00 \mathrm{a}$ & $2.52 \mathrm{bc}$ & $2^{\text {nd }}$ \\
\hline NY15 & $1.00 \mathrm{a}$ & $3.51 \mathrm{~cd}$ & $1.00 \mathrm{a}$ & $1.00 \mathrm{a}$ & $1.63 \mathrm{ab}$ & $1^{\mathrm{st}}$ \\
\hline NY17 & $2.92 \mathrm{~g}$ & $5.18 \mathrm{f}$ & $1.00 \mathrm{a}$ & $1.00 \mathrm{a}$ & $2.53 \mathrm{bc}$ & $2^{\text {nd }}$ \\
\hline NY18 & $1.00 \mathrm{a}$ & $2.77 \mathrm{a}$ & $1.00 \mathrm{a}$ & $1.00 \mathrm{a}$ & $1.44 \mathrm{a}$ & $1^{\mathrm{st}}$ \\
\hline NY19 & $1.00 \mathrm{a}$ & $4.03 \mathrm{de}$ & $1.00 \mathrm{a}$ & $1.00 \mathrm{a}$ & $1.76 \mathrm{ab}$ & $1^{\mathrm{st}}$ \\
\hline NY20 & $1.00 \mathrm{a}$ & $2.99 \mathrm{ab}$ & $1.00 \mathrm{a}$ & $1.00 \mathrm{a}$ & $1.50 \mathrm{a}$ & $1^{\mathrm{st}}$ \\
\hline NY21 & $1.00 \mathrm{a}$ & $3.45 \mathrm{c}$ & $1.00 \mathrm{a}$ & $1.00 \mathrm{a}$ & $1.61 \mathrm{ab}$ & $2^{\text {nd }}$ \\
\hline NY22 & $4.37 \mathrm{e}$ & $3.65 \mathrm{~cd}$ & $1.00 \mathrm{a}$ & $1.00 \mathrm{a}$ & $2.51 \mathrm{bc}$ & $3^{\text {rd }}$ \\
\hline
\end{tabular}

Different letters within a column indicate significant differences between treatments at $P<0.05$. 
Table 5: Solubilization of the different rock phosphates (RP) by isolates from Santchou soil sample.

\begin{tabular}{|c|c|c|c|c|c|c|}
\hline \multirow[b]{2}{*}{ Isolates } & \multicolumn{5}{|c|}{ Index of solubilization (IS) } & \multirow{2}{*}{$\begin{array}{c}\text { Speed of } \\
\text { solubilization } \\
\text { (day) }\end{array}$} \\
\hline & $\begin{array}{c}\text { Algerian } \\
\text { RP }\end{array}$ & $\begin{array}{c}\text { Malian } \\
\text { RP }\end{array}$ & $\begin{array}{c}\text { Moroccan } \\
\text { RP } \\
\end{array}$ & $\begin{array}{c}\text { Mexican } \\
\text { RP }\end{array}$ & Average & \\
\hline SA1 & $3.23 \mathrm{~b}$ & $4.34 \mathrm{~cd}$ & $1.00 \mathbf{a}$ & $1.00 \mathbf{a}$ & $2.39 \mathrm{c}$ & $3^{\text {rd }}$ \\
\hline $\mathrm{SA} 2$ & $1.00 \mathrm{a}$ & $4.13 \mathrm{c}$ & $1.00 \mathrm{a}$ & $1.00 \mathrm{a}$ & $1.78 \mathrm{ab}$ & $3^{\text {rd }}$ \\
\hline SA5 & $1.00 \mathrm{a}$ & $3.32 \mathrm{~b}$ & $1.00 \mathrm{a}$ & $1.00 \mathrm{a}$ & $1.58 \mathrm{a}$ & $2^{\text {nd }}$ \\
\hline SA9 & $3.33 \mathrm{~b}$ & $1.00 \mathrm{a}$ & $1.00 \mathrm{a}$ & $7.24 \mathrm{~d}$ & $3.14 \mathrm{~d}$ & $1 \mathrm{st}$ \\
\hline SA11 & $1.00 \mathrm{a}$ & $4.00 \mathrm{c}$ & $1.00 \mathrm{a}$ & $1.00 \mathrm{a}$ & $1.75 \mathrm{ab}$ & $3^{\text {rd }}$ \\
\hline SA13 & $1.00 \mathrm{a}$ & $4.43 \mathrm{~cd}$ & $1.00 \mathrm{a}$ & $1.00 \mathrm{a}$ & $1.86 \mathrm{~b}$ & $2^{\text {nd }}$ \\
\hline SA18 & $5.77 \mathrm{c}$ & $3.33 \mathrm{~b}$ & $3.92 \mathrm{~b}$ & $3.69 \mathrm{c}$ & $4.18 \mathrm{e}$ & $2^{\text {nd }}$ \\
\hline SA19 & $3.83 \mathrm{~b}$ & $3.33 b$ & $4.50 \mathrm{bc}$ & $2.70 \mathrm{~b}$ & $3.59 \mathrm{de}$ & $2^{\text {nd }}$ \\
\hline SA23 & $5.59 \mathrm{c}$ & $4.94 \mathrm{~d}$ & $4.57 \mathrm{c}$ & $1.00 \mathrm{a}$ & $4.03 \mathrm{e}$ & $1^{\mathrm{st}}$ \\
\hline
\end{tabular}

Different letters within a column indicate significant differences between treatments at $P<0.05$.

Table 6: Ability of rock phosphates to be solubilized by the different isolates from the three sampling sites.

\begin{tabular}{lcccc}
\hline Type PR & \multicolumn{4}{c}{ Index of solubilization (IS) } \\
\hline Algérie & $3,43 \mathbf{c}$ & $2,05 \mathbf{c}$ & $2,20 \mathbf{b}$ & $2.56 \mathbf{c}$ \\
Mali & $3,52 \mathbf{c}$ & $3,63 \mathbf{~ d}$ & $2,70 \mathbf{c}$ & $3.28 \mathbf{~ d}$ \\
Maroc & $1,13 \mathbf{~ a ~}$ & $1,13 \mathbf{a}$ & $1,71 \mathbf{~ a}$ & $1.32 \mathbf{a}$ \\
Mexique & $1,85 \mathbf{b}$ & $1,47 \mathbf{b}$ & $1,76 \mathbf{~ a}$ & $1.69 \mathbf{b}$
\end{tabular}

Different letters within a column indicate significant differences between the treatments at $P<0.05$.

\section{DISCUSSION}

The soil samples collected from the three different locations are all acidic with $\mathrm{pH}$ below 6 . Acidity generally characterized the soils from the southern part of Cameroon.

The soils available phosphorus are 6.54 ppm, $10.61 \mathrm{ppm}$, and $15.42 \mathrm{ppm}$ respectively for Nyokon, Santchou and Nkolbisson and can be qualified as soils of low available phosphorus (Giroux and Tran, 1996). However, according to the rice minimum requirement of soil available phosphorus which is about $10 \mathrm{ppm}$ (IRRI, 1970; Boudoudou et al., 2009), these soils can be considered as deficient for Nyokon, with moderate amounts for Santchou and Nkolbisson. The last two cases may be due to the amendment applied in those rice fields respectively belonging to the Centre of Agricultural Research for Development in Nkolbisson, and for SODERIM, an old rice
Cameroonian company in recovery for Santchou site. Thus, in order to improve their production, considerable amendments are made on these farm fields. Furthermore, the amounts of available phosphorus obtained from those soil samples highlight the limits of the use of soluble phosphorus amendments in southern Cameroonian soils (Fankem et al., 2006), because of their acidity and their high iron and aluminum concentration, leading most $(75-90 \%)$ of the soluble phosphate into insoluble complexes such as iron and aluminum phosphates (Supanjani et al., 2006). The Nyokon site, which is cultivated for the first time, received no amendment.

The proportions of isolates solubilizing rock phosphates obtained from the different locations allowed considering the Nyokon soil as the densest with $52.80 \%$. It is followed by Nkolbisson with $48 \%$ and finally by Santchou soil which is less populated in PSM with 
$22.44 \%$. Those proportions are not far from the findings of Kucey et al. (1989), according to whom the proportions of PSM in arable soils range between 10 and 50\%, with an average of $40 \%$. In addition, the proportion of PSM in Santchou soil is almost the half of those of Nkolbisson and Nyokon soils. This can be explained by the soil composition in small quantities of organic matter and would be explained also by a low value of the $\mathrm{C}$ : $\mathrm{N}$ ratio, against strong values of organic matter encountered in Nyokon soil. This relationship been highlighted earlier by Garcia et al. (1974) in a study on microbial activities in soils of paddy fields in Senegal. More important is the amount of available phosphorus in soil, less is the proportion of MSP.

The microorganisms were isolated and purified on nutrient agar which is a nonselective medium, to promote the growth of the greater diversity of microorganisms in the soil samples. Several researchers have also used this medium to isolate microorganisms; for instance, Islam et al. (2006) in isolation and assessment of the potential of bacteria in solubilizing the rice rhizoplane phosphate in Bangladesh.

The morphological description of pure colonies is an attempt for preliminary identification of isolates. This allowed assessing the microbial diversity of the different sites and highlighting the similarities and differences between the different isolates. This technique was earlier used by Atekan et al. (2014) who, on the same basis determined 8 isolates solubilizing phosphate from sugar cane waste.

The evaluation of the solubilization ability of isolates shows a wide range index of solubilization ranging between 2.70 and 7.24, depending on isolate. That range is close to the one ( 2.16 and 6.23 ) obtained by Maliha et al. (2004). With an average index of solubilization of 4.38 , the NK43 isolate from Nkolbisson is the strongest, it is followed by isolate NY5 ( $\mathrm{IS}=4.28$ ) from Nyokon and then by isolate SA18 (IS=4.18). Based on the solubilization potential, the different isolates can be grouped according to the IS range established by Berraquero et al. (1976) and Silva Filho and Vidor (2000): low (SI < 2), medium $(2<\mathrm{SI}<3)$ or high solubilization capacity (SI > 3). In general, of a total of 46 phosphate solubilizing isolates recorded in the three sampling sites, 20 are of low solubilization, 16 of medium solubilization and 10 of high solubilization. Obvious correlation can be observed while comparing the MPN of phosphate solubilizing microorganisms from the different soil samples $(52.8 \%$ for Nyokon, $48 \%$ for Nkolbisson and 22.44 for Santchou) with those obtained during the assessment of the ability of those isolates in solubilizing phosphates on plates, (82.6\% for Nyokon, $78.26 \%$ for Nkolbisson and 47.36 for Santchou). However, the high percentages obtained on plates might be based on physical and chemical properties of phosphates used during the two processes.

\section{Conclusion}

The isolates able to solubilize the rock phosphates of different origins were found in rice rhizospheric soils collected in all the sampling sites. This ability was found through halo detection method on plates supplemented with different sparingly soluble rock phosphates. The morphological description of the isolates allowed highlighting the relationships between the different isolates from the different sites. These results support the findings of several authors concerning the phosphate solubilizing ability of some main genera of bacteria and fungi. This is the first work reporting phosphate solubilizing microorganisms on rice rhizosphere in Cameroon. Studies are in progress for identifying and evaluating the effect of inoculation with those isolates on the growth and phosphorus uptake of rice plants under nursery and field conditions.

\section{ACKNOWLEDGEMENTS}

The authors would like to thank the head of the Laboratory of Plant Biology and Physiology, Faculty of Science, The University of Douala.

\section{REFERENCES}

Ahemad M. 2015. Phosphate solubilising bacteria assisted phytoremediation of metalliferous soil: a review. Biotech 5: 
111-121. Doi: 10.1007/s13205.014. 0206.0.

Ambassa-Kiki R, Babalola O. 2000. Jachères améliorées et restauration de la fertilité d'un sol ferrallitique $\mathrm{du}$ Cameroun central. In La Jachère en Afrique Tropicale, Floret $\mathrm{CH}$, Pontanier R (eds.). 587-593.

Antoun H. 2012. Beneficial Microorganisms for the Sustainable Use of Phosphates in Agriculture. Procedia Engineering, 46: 62 - 67. doi: 10.1016/j.proeng. 2012.09.446.

Atekan Y, Nuraini E, Handayanto S. 2014. The potential of phosphate solubilizing bacteria isolated from sugarcane wastes for solubilizing phosphate. Journal of Degraded and Mining Lands Management, 1: 175-182.

Bachelier G. 1959. Etude pédologique des sols de Yaoundé. Contribution à l'étude de la pédogenèse des sols ferrallitiques. Agron. Trop., 3: 279-305.

Berraquero FR, Baya AM, Cormenzana AR. 1976. Establishment of indices for the study of phosphate solubilization by soil bacteria. Ars Pharmacéutica, 17: 399406.

Boudoudou H, Hassikou R, Touhami OA, Badoc A, Douira A. 2009. Paramètres physicochimiques et flore fongique des sols de rizières Marocaines. Bull. Soc. Pharm., 148: 17-44.

Claisse G, Laplante A. 1953. Rapport pédologique préliminaire sur la première réunion de la commission dite des Bamboutos (Dschang 16-21 février 1953). Yaoundé : ORSTOM, 1953, 17 p. http://www.documentation.ird.fr/hor/fdi:1 2697.

Collavino MM, Sansberro PA, Mroginski LA, Aguilar MO. 2010. Comparison of in vitro solubilization activity of diverse phosphate-solubilizing bacteria native to acid soil and their ability to promote Phaseolus vulgaris growth. Biol. Fertil. Soils, 46: 727-738.

Fankem H, Nwaga D, Deubel A, Dieng L, Merbach W, Etoa F- X. 2006. Occurrence and functioning of phosphate solubilizing microorganisms from oil palm tree (Elaeis guineensis) rhizosphere in
Cameroon. African Journal of Biotechnology, 5: 2450-2460.

Fankem H. 2007. Occurrence and potentials of phosphate solubilizing microorganisms associated with oil palm (Elaeis guineensis Jacq.) rhizosphere in Cameroon. PhD thesis, University of Yaoundé I, Cameroon, p. 135.

Fankem H, Ngo Nkot L, Deubel A, Quinn J, Wolfgang M, Etoa F-X, Nwaga D. 2008. Solubilization of inorganic phosphates and plant growth promotion by strains of Pseudomonas fluorescens isolated from acidic soils of Cameroon. African Journal of Microbiology Research, 2: 171-178.

Fankem H, Tchuisseu Tchakounte GV, Ngo Nkot L, Nguesseu Njanjouo G, Nwaga D, Etoa F-X. 2014. Maize (Zea mays) growth promotion by rock-phosphate solubilizing bacteria isolated from nutrient deficient soils of Cameroon. African Journal of Microbiology Research, 8(40): 3570-3579.

Garcia J-L, Raimbault ., Jacq V, Rinaudo G, Roger P. 1974. Activités microbiennes dans les sols de rizières du Sénégal : Relations avec les caractéristiques physico-chimiques et influence de la rhizosphère. Bio Sols, 11: 170-185.

Gaume A. 2000. Low P tolerance of various maize cultivars; the contribution of the root exudation. $\mathrm{PhD}$ thesis, Swiss Federal institute of Technology, Zurich, Switzerland.

Giroux M, Tran TS. 1996. Critères agronomiques et environnementaux liés à la disponibilité, la solubilité et la saturation en phosphore des sols agricoles du Québec. Agrosol, 9: 51-57.

Goldstein AH. 2007. Future trends in research on microbial phosphate solubilization: onehundredyears of insolubility. In First International Meeting on Microbial phosphate solubilization, Velazquez E, Rodriguez-Barrueco C. (eds). Springer: Dordrecht; 91-96.

Guiñazu LB, Andres JA, Del Papa MF, Pistorio M, Rosas SB. 2010. Response of alfalfa (Medicago sativa L.) to single and mixed inoculation with phosphatesolubilizing bacteria and Sinorhizobium meliloti. Biol. Fertil. Soils, 46: 185-190. 
IRRI. 1970. Annual report for 1969, IRRI, $266 \mathrm{p}$.

Islam MT, Deora A, Hashidoko Y, Rahman A, Ito T, Tahara S. 2006. Isolation and Identification of Potential Phosphate Solubilizing Bacteria from the Rhizoplane of Oryza Sativa L. cv. BR29 of Bangladesh. Z. Naturforsch, 62: 103110.

Jayadi M, Baharuddin, Ibrahim B. 2013. In vitro selection of rock phosphate solubility by microorganism from Ultisols in South Sulawesi, Indonesia. American Journal of Agriculture and Forestry, 1(4): 68-73.

Jorquera MA, Hernandez MT, Rengel Z, Marschner P, Mora M. 2008. Isolation of culturable phosphobacteria with both phytatemineralization and phosphatesolubilization activity from the rhizosphere of plants grown in a volcanic soil. Biol. Fertil. Soils, 44: 1025-1034.

Khan MS, Zaidi A, Wani PA. 2009. Role of phosphate solubilizing microorganisms in sustainable agriculture. In Sustainable Agriculture. Lichtfouse E, Navarrete M, Debaeke $\mathrm{P}$, Véronique S, Alberola C. (eds) Springer, p 551-570, doi: 10.1007/978-90-481-2666-8_34.

Kim KY, Jordan D, Krishnan HB. 1997. Rahnella aqualitis, a bacterim isolated from soybean rhizosphere, can solubilize hydroxyapatite. FEMS Microbiol. Lett., 153: 273-277.

Kpomblekou K, Tabatabai MA. 1994. Effect of organic acids on release of phosphorus from phosphate rocks. Soil Sci., 158: 442-453.

Kucey RMN, Janzen HH, Leggett ME. 1989. Microbially mediated increases in plantavailable phosphorus. Ad. Agron., 42: 199-228.

Leyva GR, Rizo AG, Armas RG, Pérez MD, Bruzón Aguila RY, Soto WR. 2011. Obtaining bacterial isolates from soil Samples from the western region of Cuba. Institutional magazine of the entrepreneurial group of biopharmaceutical and chemical products. LABIOFAM, $n^{\circ}$ 1/2011.

Maliha R, Khalil S, Ayub N, Alam S, Latif F. 2004. Organic acids Production and
Phosphate Solubilization by Phosphate solubilizing Microorganisms (PSM) Under in vitro Conditions. Pakistan Journal of Biological Sciences, 7: 187196.

Marra LM, Oliveira SM, Soares CRFS, Moreira FMS. 2011. Solubilization of inorganic phosphates by inoculant strains from tropical legumes. Scientia Agricola, 68(5): 603-609. http://dx.doi.org/10.1590 /S0103-90162011000500015.

Martin D, Segalen P. 1966. Notice Explicative - Carte Pédologique Du Cameroun Orientale au L/ 1.000000.

Monica S, Harshada J. 2015. Study of phosphate solubilising ability of lead tolerant Pseudomonas aeruginosa HMT51 isolated from Zawarmines, Udaipur. India Res. J. Recent. Sci. 5: 280-282.

Nautiyal CS. 1999. An efficient microbiological growth medium for screening phosphates solubilizing microorganisms.FEMS Microbiol. Lett., 170: 265-270.

Oteino N, Lally RD, Kiwanuka S, Lloyd A, Ryan D, Germaine KJ, Dowling DN. 2015. Plant growth promotion induced by phosphate solubilizing endophytic Pseudomonas isolates. Front. Microbiol. 6: 745. doi: 10.3389/fmicb.2015.00745.

Popavath RN, Gurusamy R, Kannan BN, Natarajan S. 2008. Assessment of genetic and functional diversity of phosphate solubilizing fluorescent pseudomonads isolated from rhizospheric soil. $B M C$ Microbiology, 8: 230. doi:10.1186/14712180-8-230.

Qureshi MA, Ahmad ZA, Akhtar N, Iqbal A, Mujeeb F, Shakir MA. 2012. Role of phosphate solubilizing bacteria (PSB) in enhancing $\mathrm{P}$ availability and promoting cotton growth. The Journal of Animal \& Plant Sciences, 22: 204-210.

Richardson AE. 2001. Prospects for using soil microorganisms to improve the acquisition of phosphorus by plants. Aust. J. Plant Physiol., 28: 8797-906.

Richardson AE. 2009. Regulating the phosphorus nutrition of plants: molecular biology meeting agronomic needs. Plant Soil, 322: 17-24. 
Rodríguez H, Fraga R, Bashan Y. 2006. Genetics of phosphate solubilization and potential applications for improving plant growth-promoting bacteria. Plant Soil., 287: 15-21.

Rodriguez H, Fraga R, 1999. Phosphate solubilizing bacteria and their role in plant growth promotion. Biotechnol. Adv., 17: 319-339.

Sharma SB, Sayyed RZ, Trivedi MH, Gobi TA. 2013. Phosphate solubilising microbes: sustainable approach for managing phosphorus deficiency in agricultural soils. SpringerPlus, 2: 587.doi: 10.1186/2193-1801-2-587.

Shin D, Kim J, Kim BS, Jeong J, Lee JC. 2015. Use of phosphate solubilizing bacteria toleachrare Earth elements from monazite-bearing ore. Minerals 5: 189202.doi:10.3390/min5020189.

Silva Filho GN, Vidor. 2000 Phosphate solubilization by microorganisms in the presence of different carbon sources. $R$. Bras. Ci. Solo., 24: 311-319.

Supanjani HHS, Jung JS, Lee KD. 2006. Rock phosphate-potassium and rocksolubilizing bacteria as alternative, sustainable fertilizers. Agron. Sustain., 26: 233-240.

Yazdani M, Bahmanyar MA, Pirdashti H, Esmaili MA. 2009. Effect of phosphate solubilizing microorganisms (PSM) and plant growth promoting rhizobacteria (PGPR) on yield and yield components of corn (Zea mays L.). World Acad. Sci. Eng. Technol. 49: 90-92. 